\title{
Feelings, experiences and expectations of kidney transplant individuals and challenges for the nurse
}

\author{
Sentimentos, vivências e expectativas de indivíduos renais transplantados e desafios para o enfermeiro
}

Sentimientos, experiencias y expectativas de individuos renales trasplantados y desafíos para el enfermero

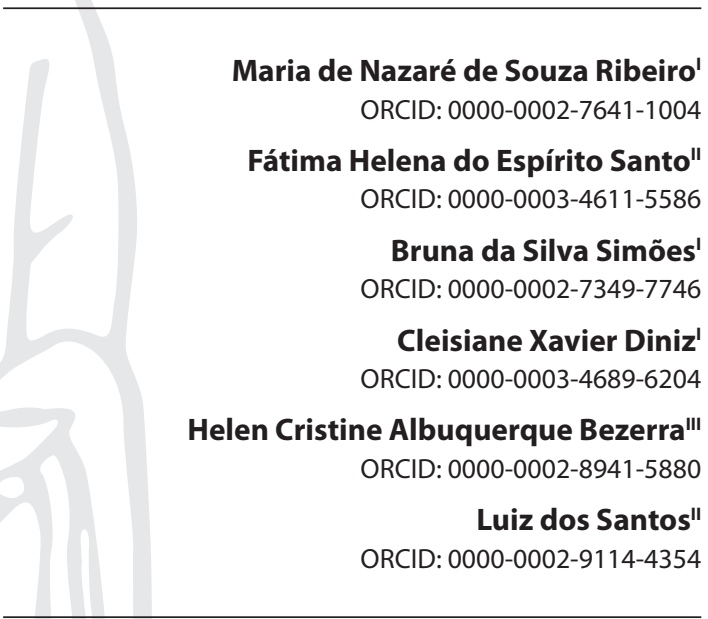

'Universidade do Estado do Amazonas. Manaus, Amazonas, Brazil.

"Universidade Federal Fluminense. Niterói, Rio de Janeiro, Brazil.

"'Universidade Federal do Amazonas. Manaus, Amazonas, Brazil.

How to cite this article: Ribeiro MNS, Santo FHE, Simões BS, Diniz CX, Bezerra HCA, Santos L. Feelings, experiences and expectations of kidney transplant individuals and challenges for the nurse. Rev Bras Enferm. 2021;74(1):e20200392. doi: http://dx.doi.org/10.1590/0034-7167-2020-0392

Corresponding author:

Maria de Nazaré de Souza Ribeiro

E-mail: mnribeiro2@gmail.com

EDITOR IN CHIEF: Antonio José de Almeida Filho ASSOCIATE EDITOR: Ana Fátima Fernandes

Submission: $04-28-2020$

Approval: 08-18-2020

\section{ABSTRACT}

Objectives: to identify feelings, experiences, and expectations of kidney transplant patients, generated from the diagnosis of chronic renal disease until the post-transplant period, highlighting the challenges for nurses to incorporate individualized care to cope throughout the disease process. Methods: qualitative, descriptive research, carried with seven kidney transplant patients, in the city of Manaus, State of Amazonas. The data analysis followed the methodological referential of Bardin's content analysis. Results: the diagnosis of the disease was experienced negatively, and hemodialysis was described as an imprisonment and health decline. The transplant meant an improvement in quality of life. The main difficulties were lack of a specialized hospital and low immunity. Conclusions: the nurses' approach of chronic renal patient and with the renal transplantation favored the discovery of solutions facing the demands of the disease and allowed greater capacity to implement individualized care, surrounding a relationship of trust and respect.

Descriptors: Female and Male Nurses; Transplant; Kidney Transplant; Life Changing Events; Nephrology Nursing.

\section{RESUMO}

Objetivos: identificar sentimentos, vivências e expectativas de indivíduos renais transplantados, gerados desde o diagnóstico de Doença Renal Crônica até o período pós-transplante, destacando os desafios para o enfermeiro na incorporação de cuidados individualizados de enfrentamento durante todo o processo da doença. Métodos: pesquisa qualitativa, descritiva, realizada com sete transplantados renais, na cidade de Manaus, Amazonas. A análise dos dados seguiu o referencial metodológico da análise de conteúdo de Bardin. Resultados: o diagnóstico da doença foi vivenciado de forma negativa, e a hemodiálise foi descrita como aprisionamento e declínio. O transplante significou melhora da qualidade de vida. As principais dificuldades foram falta de hospital especializado e baixa imunidade. Conclusões: a aproximação do enfermeiro com o doente renal crônico e com o transplantado renal favorece o encontro de soluções diante das exigências da doença e permite-lhe maior capacidade para implementar cuidados individualizados, envoltos em uma relação de confiança e respeito.

Descritores: Enfermeiras e Enfermeiros; Transplante; Transplante de Rim; Acontecimentos que Mudam a Vida; Enfermagem em Nefrologia.

\section{RESUMEN}

Objetivos: identificar sentimientos, experiencias y expectativas de individuos renales trasplantados, generados desde el diagnóstico de enfermedad renal crónica hasta el postrasplante, destacando los desafíos para el enfermero en la incorporación de cuidados individualizados de enfrentamiento durante el proceso de la enfermedad. Métodos: investigación cualitativa, descriptiva, con siete trasplantados renales, en Manaus, Amazonas. El análisis de los datos siguió el referencial metodológico del análisis de contenido de Bardin. Resultados: el diagnóstico de la enfermedad ha vivido de forma negativa, y la hemodiálisis ha sido descripta como reclusión y declive. El trasplante significó mejora de la calidad de vida. Las principales dificultades fueron falta de hospital especializado y baja inmunidad. Conclusiones: el acercamiento del enfermero con el enfermo renal crónico y con el trasplantado renal favorece el encuentro de soluciones delante las exigencias de la enfermedad y le permite mayor capacidad para implementar cuidados individualizados, en una relación de confianza y respecto.

Descriptores: Enfermeras y Enfermeros; Trasplante; Trasplante Renal; Acontecimientos que Cambian la Vida; Enfermería en Nefrología. 


\section{INTRODUCTION}

Chronic non-communicable or chronic diseases (NCD) are responsible for more than half of causes of death worldwide, affecting approximately 35 million people each year. Among NCDs are included chronic renal disease (CKD), which affects about $5 \%$ to $10 \%$ of the world's population and whose occurrence has been increasing in Brazil, being associated, most of all, to the high number of people with hypertension and diabetes mellitus, as well as the aging population ${ }^{(1-3)}$.

Considered a public health problem, CKD is characterized by an insidious, irreversible, and progressive pathological process of renal function loss. Patients progressing to terminal CKD need to make use of renal replacement therapies (RRT) such as hemodialysis, peritoneal dialysis, or kidney transplant, considered the fifth stage of the CKD process ${ }^{(1-4)}$. Among the treatment modalities for CKD, the kidney transplant is the best therapeutic modality and, in certain cases, it may represent the only way for the individual to survive ${ }^{(4-5)}$. This procedure causes an important stress load, several psychological, existential, affective, relational and social changes, both for the individual and for those who participate in his or her life context ${ }^{(3)}$.

In Brazil, between January and December 2018, were performed 23.538 transplantations, which 5.923 were kidney transplants ${ }^{(6)}$. In 2015, 84.347 kidney transplants were performed worldwide, representing an increase of 5.5\% compared to 2014 , but that is considered a number below global demand; $80 \%$ of all kidney transplant patients reside in North America or Europe ${ }^{(7)}$.

The purpose of kidney transplant is to improve quality of life for the individual desolated by hemodialysis sessions, giving back to the patient the possibility of a longer life with better quality, if compared to his/her pre-transplant experience. However, although there is an improvement in quality of life after kidney transplant, the individual experiences changes in the routine, such as incorporate the use of immunosuppressants ${ }^{(8)}$, frequent visits to the hospital to evaluate health progress and experience a feeling of fear regarding the rejection of the graft ${ }^{(9-10)}$.

As well as with other forms of renal replacement therapy, the transplant persons are even more susceptible to develop complications. Post-transplant complications vary from the most common to the extremely complex, such as infections, urological complications, and graft rejection - all likely to lead to hospitalization and may compromise their quality of life $\mathrm{e}^{(11)}$. Studies point to a high risk of depression, anxiety, sleep loss and other psychiatric disorders, with repercussions on quality of life and risk of rejection, indicating the need for psychosocial follow-up before, during and after transplant ${ }^{(3,8,11)}$.

In an integrative literature review, which did not include stage 5 of CKD, the authors found a single qualitative study with patients in stage 1 to 4 who expressed their concerns and uncertainties about the future. Other surveys have highlighted the same feelings, although in isolated phases, without addressing the periods such as before, during and after transplant ${ }^{(12)}$. So, some gaps on the subject were identified in the research, and if they could have been filled would help to clarify the feelings, experiences and expectations produced by the transplanted kidney patients in the process of experiencing CKD, transplant and post-transplant, since the subject is filled with concerns that stimulate scientific research in the area. It is also important to emphasize that nursing was the scientific area with the largest number of published studies related to kidney transplants and life context, but only in very specific phases of $\mathrm{CKS}^{(12)}$. Studies show that care strategies employed by nurses, based on a relationship of trust, help the patient to improve coping with the disease and adherence to treatment ${ }^{(13-15)}$.

In view of this, the following questions have arisen: What are the feelings, experiences, and expectations of kidney transplant individuals, generated since the diagnosis of CKD until the post-transplantation period? How can nurses help kidney transplant patients incorporate new coping adaptations during the entire disease process?

It is believed that identifying the feelings, experiences and expectations of transplanted people can provide an understanding of the general context in which they find themselves, enabling the realization of approaches more appropriate to the real needs of these individuals.

\section{OBJECTIVES}

To identify feelings, experiences, and expectations of kidney transplant individuals, generated from the diagnosis of CKD to the post-transplant period, highlighting the challenges for the nurse in incorporating individualized care to address the entire process of the disease.

\section{METHODS}

\section{Ethical Aspects}

This research was submitted to and approved by the Research Ethics Committee (CEP) of the State University of Amazonas (UEA) and complied with the ethical principles involving studies with human beings determined in Resolution 466/12 of the National Health Council.

To guarantee the anonymity of the participants, their names have been identified by a code, i.e. the letter " $E$ " to indicate the interviewee, followed by the number corresponding to the order $(\mathrm{E} 1, \mathrm{E} 2, \mathrm{E} 3 \ldots \mathrm{E}$ ) $)$. After becoming aware of the objective of the survey, all authorized their participation with the signature of the Term of Free and Informed Consent (TCLE).

\section{Type of study}

This is a qualitative, descriptive research, carried out with seven kidney transplant individuals living in the city of Manaus (AM). It was not intended to study the phenomenon itself, but to understand the meaning for the individual's life. In this way, discussing the feelings, experiences, and expectations of kidney transplant individuals demands, above all, the appreciation of the subjectivity of these people, which has become possible through this approach. The study was guided by the precepts of the Consolidated Criteria for Reporting Qualitative Research (COREQ).

\section{Methodological procedures}

For the sample selection, it was used a non-probabilistic technique called "snowball"(16), which uses reference chains, in which one individual indicates another, to study populations difficult to be accessed, until a discursive recurrence of the data presents itself. The 
sample consisted of seven kidney transplant individuals, computed from the recurrence of speech contents and the complementarity information required for the study. The data gathering period occurred between November 2018 and May 2019.

After identification data, gathered by a questionnaire containing the variables name, gender, age, marital status, education, organ origin, time of renal therapy and transplant, the interview began by a prompting question, which offered further developments: "What happened to your life since the discovery of the disease and a possible need for kidney transplant?

\section{Study scenario}

The study was conducted in the city of Manaus, where, between 2011 and 2018, 232 kidney transplants were performed, which 93 were from living donors, and 139 from deceased donors ${ }^{(6)}$. For the study it was considered only individuals transplanted more than one year ago, that is, from 2018 and previous years. To ensure privacy and a friendly environment, the interview location was the Laboratory of the Health Sciences and Humanities Research Group (LaPeCSH), at the School of Health Sciences of the UEA, attached to the school hospital and the kidney and liver transplant center, Adriano Jorge Hospital Foundation (FHAJ), from whose outpatient clinic the sample was selected.

\section{Data source}

For participants selection it was adopted the following inclusion criteria: individuals over 18 years of age, both genders, residents in the city of Manaus, not self-reported as indigenous ethnic group, undergone kidney transplant for over a year (regardless the place where the surgery was performed) and in follow-up at the nephrology clinic of FHAJ. The exclusion criteria were people with difficulty to understand and answer the interview or who, for some reason, could be harmed by this study. Using the snowball technique, all the participants were indicated by an interviewee who preceded him/her in the study. The first one was indicated by the coordination of the Amazonas Organ Search Organization (OPO-AM), for being part of the program to encourage organ donation in the state and the representative of the renal transplanted patients, accompanied at the FHAJ outpatient clinic. The indication of the first interviewee by OPO-AM and the support given to the survey facilitated the access and acceptance of the other participants.

\section{Data gathering and organization}

The interviews were previously scheduled, reconfirmed by phone, and privately recorded in the LaPeCSH. The interview time ranged from 64 to 180 minutes. Two digital devices were used for the recording to guarantee the integrity of the statements. The speeches were fully transcribed, in order to preserve the original speech, and for treatment, highlighting the fundamental elements for the understanding in this study in progress and its results.

\section{Data analysis}

The data were analyzed in three systematic stages: pre-analysis, exploration of material, treatment of results obtained, and interpretation. The methodological referential adopted in this research is the content analysis technique proposed by Bardin ${ }^{(17)}$, which has as purpose the survey of indicators that allows to achieve the knowledge inference.

Interview readings, identification of common themes and grouping into categories were done to better understand the content. The interpretation took place through the inference of data gathered from the scientific literature. The interviews originated a corpus of analysis, whose units presented significant singularities and homogeneity, being grouped in four thematic categories: the impact of an unknown diagnosis; living with the hemodialysis machine; values and expectations attributed to the current transplanted condition; and difficulties that permeate the current life of the kidney transplant individual.

\section{RESULTS}

Seven people participated in the study, among them four women, aged between 32 and 55. Regarding marital status, four were single, two married and one widower; three of them had completed higher education and two had incomplete education; the rest did not complete elementary school. The duration of RRT varied between 1 and 13 years. Three patients received the organ from a cadaver donor and four from a living donor (spouse, daughter, father, and brother). The transplant time varied between 1.7 and 22 years, and three patients performed the transplant outside the state of Amazonas.

\section{Impact of an unknown diagnosis}

In this category, the participants revealed their feelings since the revelation of the diagnosis of CKD. The discovery of the disease, linked to the immediate onset of hemodialysis, was experienced by the participants in a negative and painful way. Feelings of shock, sadness, pain, and surprise were present in each participant's speech. The interviewees considered this process a difficult situation to accept, influencing directly their emotional and psychic aspects.

I was referred to the nephrologist. When I got there, my pressure was $230 \times 170$ and I was just how I am with you now, without feeling anything [...]. Then she said: "Your tests are like this and that [...] you will need hemodialysis". Imagine my surprise! That's it, my world was over! (E1)

I cried [...] and cried for many years after I discovered the kidney problem. I didn't understand what was wrong with me. But the social worker told me that it was a serious problem, that I could die, and the only way for me to survive was to be part of the process. And I cried a lot because I felt very bad. You feel bad 24 hours a day, it is very bad. (E3)

The experience of illness and the way the person is related to CKD was always unique and subjective and depended on several factors - in particular, the psychological profile. It was understood that kidney disease brought negative feelings, such as unhappiness, fear, loneliness, and disability, in addition to experience a premature mourning when facing the diagnosis. 
It was all extremely fast; I was surprised! Nobody expected it! It was a commotion in the family [...]. What was colorful became dark, I lost my smile, and everything lost its meaning. My joy was over because I saw that I had something serious. Then, at the same time, he [the doctor] alerted me that I was on the verge of a stroke and told me to do catheterization and then hemodialysis. It was all quick and bad. I was very scared! I was young, I was 35 years old and I didn't have anyone on my side to support me. (E5)

When I turned to be a kidney patient, I thought my life was over! Because I was always very agitated, I always wanted to run after things, in college, at work. (E6)

The first signs of the disease mentioned by the interviewees were lumbar pain, abdominal pain, edema, nausea, presence of intense anemia and weakness. Some interviewees reported having postponed the search for specialized care.

I started to feel a lot of pain in my back and when I sat down, I felt a lot of pain in my belly. And I realized that I was swollen, that I was nauseated. (E3)

I was very anemic, I was very anemic, then I passed out. When I went to the doctor, he realized it was a kidney problem. I felt a lot of things, but we imagine it goes away. I didn't think that the kidney was stopping. (E7)

\section{Living with the hemodialysis machine}

Life before transplantation, in the hemodialysis machine, was described by the participants as a period characterized by limitations imposed by the dialysis treatment. The main difficulties were dietary restrictions, strict hydric control, and the impacts of the treatment.

I felt very nauseous and I couldn't eat anything, feeling an extreme weakness, very nauseous, which only passed after I threw up everything. I ate little, because at this stage you can't eat much meat, not much fruit. Then what will you eat? It's hard! The meat was unsalted, only seasoned with garlic, and usually roasted; fruit only cooked on account of the potassium. (E3)

At first it was hard because I didn't understand why I was there. I wanted to drink water and I could not. I was angry. And I still had diabetes to make things worse [...] so it was quite complicated. (E6)

Symptomatological effects of dialysis treatment, such as hypotension, headache, nausea, and discomfort, were also experienced during and after hemodialysis.

I felt only when my pressure dropped while on hemodialysis. I think that in almost 3 years of hemodialysis I felt sick two or three times. (E4)

Over time I began to experience terrible reactions. A mixture of everything: headache, vomiting and a malaise which I can't even describe. And it only happened at dawn or after 24 hours of living with those horrible reactions. (E5)

It was present the feelings of uselessness and imprisonment after the hemodialysis sessions, increased by the fact of not being able to develop daily and work activities, due to the physical decline resulting from the treatment.

At the time of hemodialysis, I was not well! It was just staying at home one day recovering from the blow, because we take out $4 \mathrm{~kg}$ of impurity in the machine; it takes out everything. Then [...] one day I recovered from it and the next day I must go again. There was no life to do anything, it was just that, vegetating all the time; it was home and hemodialysis. I didn't study, didn't work, didn't leave the house, didn't do anything. (E7)

\section{Values and expectations attributed to the current condi- tion as renal transplanted patient}

In this category, the individuals attributed values to their current condition as transplanted patients, related to subjectivity and influenced mainly by the individual perception of the events experienced and the relationship with health. For these individuals, the transplant represented rebirth and feeling of well-being, which were attributed as values due to the chance to have a new life, the feeling of freedom and the improvement in the quality of life.

The representations that the individual has built up about transplantation, the quality and life expectations have been configured as positive experiences after the transplant.

After I transplanted, it was another life. I have escaped, I have lived again, I look the brightness of the day, you know, and for me it is a wonder! (E2)

I can eat, drink, sleep, travel, study, do what I want. I don't feel anything anymore and I'm not stuck anymore. (E7)

With the freedom resulting from the transplant, most of the participants stated the desire to continue their working activities and continue with the studies.

Professionally speaking, I am very keen to go after a publicjob. (E1)

I want to try to get a master's degree, but before that, I already want to be able to teach in the second semester to complementmyincome. (E6)

As positive post-transplant experiences, participants pointed out altruism, body care and health as something of great importance developed from experiences with the disease and transplantation.

I think the only thing I see positive about this is that you become a better person, you try to become a better person, because you have already suffered so much. (E3)

As for the positive experiences, I can say that this has re-educated me about nutrition, to take better care of my body and my health [...]. Good nutrition and specific exams help us to identify problems like I had. If I had known before that the exams that measures the kidney health were urea and creatinine, I wouldn't have gone through this. (E5)

\section{Difficulties that permeate the current life of the kidney transplant individual}

Post-transplant difficulties experienced by the participants emerged in the speeches. The narratives indicated the difficulty 
of not having a specialized hospital for transplants, the low immunity, and the fear of losing the transplanted organ.

There is still a lot of difficulty not only for me. For all transplants, the biggest difficulty is the [emergency] service. For example, we know that we do not have the health like you who are not transplanted, our immunity is zero. So, suppose I am home and feel sick, I have to run to the general hospital. We don't have something like the cancer hospital, where everything is centralized. We don't have such hospital yet. (E1)

The negative side is the problem of getting sick, which for us is the biggest issue, because besides being worse, you already have such an idea in your head: "I'm going to lose my graft", and then all that film comes back in your mind, such as going back to hemodialysis again, it reminds you of everything we've been through and it's very bad. (E6)

Two important negative aspects were the difficulty to access the immunosuppressive medications and the frequent visits to the hospital to evaluate the health conditions.

There is a lack of medications at CEMA [Central de Medicamentos do Amazonas]. Sometimes we don't have to buy the medication we must take, but when we do is very expensive. But the fight is not easy! Every three months we have to consult with the physician. (E2)

What is the point of transplant? I tried so hard! I don't have medication [...] you go after it and you don't get it, you want to keep your health, but you can't, because what should work, doesn't work. So, you end up getting discouraged, because it also weakens you. This is the negative side, you want to do everything right, but there is no structure for it, because the post-transplant care requires a big structure. (E3)

Another point highlighted by the participants in the interviews was the interference of immunosuppressive medications in daily life.

The negative points are the medications because we have to take them for life! You can't forget to take them. Some change your body! (E1)

The medication interferes in your daily mood, it interferes even in your life [...]. The patient instructions is a book full of possible causes; it can even cause cancer, mainly skin cancer. The occurrence of skin lesions in the transplanted patient is frequent, so it gives a lot of wart, HPV. (E3)

\section{DISCUSSION}

The narratives presented in the category "The impact of an unknown diagnosis" revealed negative feelings towards the newly discovered diagnosis and the need for hemodialysis. The impact of the news generates a range of feelings and behaviors that showed the fear of what was going to happen. The discovery of the disease, followed by dialysis treatment, usually leads to reactions of sadness, anguish and despair ${ }^{(18-19)}$.

In the communication stage of the diagnosis, it must be emphasized the important role of the nurse in communicating the difficult news. He/she can foresee, identify, understand, and handle feelings of fear, anguish, and doubts. By establishing a connection, he helps the individual to incorporate new coping adaptations throughout the process, from diagnosis to treatment, in the hospital, family, social and work environments ${ }^{(20)}$.

In terms of the illness process, the participants were unable to detect the signs of the disease, characterizing this stage as something unpredictable. Usually individuals had no previous knowledge about the disease, due to the fact that the systemic changes appear only when the kidneys has already lost approximately $50 \%$ of their function ${ }^{(18,21)}$.

From the statements, it is possible to verify that chronic conditions require specialized handle at all levels of health assistance by the professionals involved, since the discovery of the disease causes abrupt changes in routine and in the quality of life of these individuals. In this area, nursing professionals can provide care by promoting effective communication and education actions, which are essential for the adoption of preventive measures and the possibility of an early diagnosis ${ }^{(22)}$.

In the second category, called "Living with the hemodialysis machine", the statements presented express negative perceptions about being submitted to this modality of treatment and point out similarity with other researches, which highlight changes in the physical, mental and behavioral spheres, as well as in the lifestyle $\mathrm{e}^{(9,23-24)}$. During the treatment, these people experience several negative nuances, among them the creation of an arteriovenous fistula; double-lumen graft or catheter for the treatment; dependency on a life maintenance machine; feeding restrictions; and restriction of water intake ${ }^{(9)}$. Other situations, such as dizziness, hypo/hypertension, weakness, weight loss/ gain, anemia, itching, cramp, intestinal constipation, repetitive infections and cardiac arrhythmia, are described in the literature as regular clinical intercurrences ${ }^{(20,24-25)}$.

Caring for a patient on hemodialysis means prioritizing, among the necessary interventions, those aiming at physical and psychic strengthening and self-care education, which must be incorporated into the person's life context. The nurse can help in the positive adaptation to the new and sudden lifestyle, which now includes a hemodialysis machine. This adaptation can be facilitated through direct care and educational interventions, intending to help the patient live the new reality.

As for the testimonies described in the category "Values and expectations attributed to the current condition of renal transplant", it is observed the story of a new meaning to life, the possibility of continuity in personal growth, freedom, new perspectives of well-being and challenges for adaptation. Corroborating the data presented here, surveys have also evidenced achievements, such as the independence, liberation from dialysis therapy, unrestricted fluid intake, return to social/leisure activities ${ }^{(25)}$, reduction of important stress factors and return to social and professional life $\mathrm{e}^{(26-27)}$.

Surveys prove that transplantation offers survival advantage and better quality of life, being also more cost-effective than dialysis ${ }^{(4-5,7)}$. Consequently, the positive experiences taking place thanks to transplants collaborate with the feeling of well-being emphasized by transplants, greater capacity to confrontation and recognition of improved self-image. With the help of professionals, 
transplanted individuals are usually willing to improve and maintain their health, take care of the graft and collaborate with their treatment ${ }^{(26,28)}$. When they receive psychotherapy support in pre and post-transplant, they improve the adherence of treatment and reduce the possibility of anxiety and depression onset ${ }^{(3)}$.

In a systematic review on kidney transplantation, it was observed a better adherence to drug therapy, but with difficulty in adhering to the suggested healthy lifestyle. In such cases, nurses can contribute in important ways for treatment adherence, such as: encouraging control tests; guiding and monitoring immunosuppressive therapy (dosages, regular intake, forgetfulness and side effects); encouraging an appropriate lifestyle; support the need for a healthy diet (number of daily meals, presence of industrialized food, etc.); frequent monitoring of body weight; control consultations; prevention of infections; and encouraging physical activity, smoking cessation and sun exposure. The study endorsed the fundamental role assumed by the nurse and pointed out the need for a psychoeducational preparatory course for transplant candidates ${ }^{(3)}$.

However, it is not only the patient's adherence that counts in this process. The whole journey to perform the surgery, the long waiting period to find a donor, and the insufficiency and irregularity of the medications offered by the public health service make the completion of the transplant a milestone victory. The statements in the category "Difficulties that permeate the current life of the kidney transplant individual" corroborate other studies, which also identified the same difficulties ${ }^{(28-30)}$.

In many countries, the current approach to kidney disease is not sufficient in terms of equitable access to high-quality care, nor is it sustainable for the patient and the health system. This is because kidney transplant requires several auxiliary components, such as access to tissue typing laboratories, which can be difficult to be implemented and sustained by underdeveloped and developing countries. Since all those services involve fixed costs that are amortized over the total number of transplants performed, the cost of transplantation can be irrationally high in locations where programs are new and/or perform a low number of transplants ${ }^{(7)}$.

In general, the life of these patients, whether at the beginning of kidney disease or in the post-transplant period, depends on access to early specialized assistance and right treatment decisions. Nursing plays a primordial role during the whole pre-transplant, transplant and post-transplant cycle, minimizing or avoiding suffering ${ }^{(31)}$. In this process, the involvement of the patient and his relatives is extremely important, to ensure that by planning their care all the priority needs are met. The fact that the nurse is always closer to the patient and his family allows him/her to recognize their basic human needs with more property and implement coherent health care, in an individualized manner and based on a humanized relationship of trust and respect.

\section{Study limitations}

It could be pointed out as a possible limitation of the study the reduced number of participants. However, since this is a qualitative study, there was no intention of generalizing the results.

\section{Contributions to the nursing field}

The study showed that nurses play an important role in the follow-up of kidney transplants, through implementation of actions aimed at integral care and valorization of connections as a strategy that brings solutions and favors the totality of care, corroborating with other studies ${ }^{(2,32-34)}$. Moreover, knowing the feelings, experiences and expectations of kidney transplants provides professionals with a scientific basis beyond the biological dimension.

It is noteworthy that the use of communication management skills and individualized health care strategies by nurses can help patients, in different psychological conditions, to reduce tensions, speed up their rehabilitation, improve how to cope with the disease, increase adherence to treatment and mitigate negative feelings, in addition to strengthening the level of trust in the patient-nursing relationship. The results of this study can also add some knowledge to the existing literature.

\section{CONCLUSIONS}

Starting from narratives of the participants, this study made it possible to understand various expressions of feelings, experiences and expectations of kidney transplant individuals and the changes in their lives since the diagnosis until the proposed treatments. The impact of kidney disease diagnosis was experienced in a negative and painful way, hitting these patients physically and emotionally. The period of hemodialysis was characterized by difficulties such as dietary restrictions, strict water intake control and non-intended effects from the treatment, associated with symptoms that cause the individual to feel trapped and decline in the development of their activities. The transplantation meant, for the individuals interviewed, the renewal of lost freedom and improvement of the quality of life.

The main difficulties reported were the lack of a specialized hospital for transplants, low immunity, and fear of losing the transplant. The nurses approach to the chronically ill patient and the kidney transplant patient make it possible to improve their performance in face of the demands of the disease, as well as helps to overcome the challenges of adapting to the new reality.

\section{FUNDING}

To the Amazonas Research Support Foundation (FAPEAM), which financed a Scientific Initiation scholarship.

\section{REFERENCES}

1. Ministério da Saúde (BR). Diretrizes Clínicas para o Cuidado ao paciente com Doença Renal Crônica - DRC no Sistema Único de Saúde [Internet]. Brasília, DF: Ministério da Saúde; 2014 [cited 2020 Jun 23]. Available from: https://bvsms.saude.gov.br/bvs/publicacoes/diretrizes_ clinicas_cuidado_paciente_renal.pdf 
2. Mattos LM, Nunes AC, Queiroz RM, Bonfim IM, Studart RM, Castro KS. Clinical and immunological assessment of renal transplant recipients. Rev Pesqui: Cuid Fundam. 2019;11(5):1202-7. doi: 10.9789/2175-5361.2019.v11i5.1202-1207

3. Pasquale C, Pistorio ML, Veroux M, Indelicato L, Biffa G, Bennardi N, et al. Psychological and psychopathological aspects of kidney transplantation: a systematic review. Front Psychiatry. 2020;11:106. doi: 10.3389/fpsyt.2020.00106

4. Nga HS, Andrade LG, Contti MM, Valiatti MF, Silva MM, Takase HM. Evaluation of the 1000 renal transplants carried out at the University Hospital of the Botucatu Medical School (HCFMB) - UNESP and their evolution over the years. Braz J Nephrol. 2018;40(2):162-9. doi:10.1590/2175-8239-jbn-3871

5. Mendonça AE, Torres GV, Salvetti MG, Alchieri JC, Costa IK. Changes in Quality of Life after kidney transplantation and related factors. Acta Paul Enferm. 2014;27(3):287-92. doi: 10.1590/1982-0194201400048

6. Associação Brasileira de Transplante de Órgãos (ABTO). Dimensionamento dos transplantes no Brasil e em cada Estado (2011-2018) [Internet]. São Paulo: ABTO; 2018 [cited 2020 Jun 23]. Available from: http://www.abto.org.br/abtov03/Upload/file/RBT/2018/Lv_RBT-2018.pdf

7. Harris DCH, Davies SJ, Finkelstein FO, Jha V, Donner JA, Abraham G, et al. Increasing access to integrated ESKD care as part of universal health coverage. Kidney Int. 2019;95(4S):S1-S33. doi: 10.1016/j.kint.2018.12.005

8. Leite RF, Silva AC, Oliveira PC, Silva LM, Pestana JM, Schirmer J, et al. Measurement of adherence to immunosuppressive drugs in renal transplant recipients. Acta Paul Enferm. 2018;31(5):489-96. doi: 10.1590/1982-0194201800069

9. Santos CM, Kirchmaier FM, Silveira WJ, Arreguy-Sena C. Perceptions of nurses and clients about nursing care in kidney transplantation. Acta Paul Enferm. 2015;28(4):337-343. doi: 10.1590/1982-0194201800069

10. Associação Brasileira de Transplante de Órgãos (ABTO). Grupo de Apoio aos Transplantados. Manual de Orientação ao Paciente em Transplante [Internet]. São Paulo: ABTO; 2015 [cited 2020 Jun 23]. Available from: http://www.abto.org.br/abtov03/Upload/file/GAT/ Manual_GAT_Congresso2015.pdf

11. Pinto KD, Cavalcanti NA, Maia RS, Maia EM. Quality of life and strategies of training in kidney transplantation. Rev Enferm UFPE. 2017;11(4):1799-803. doi: 10.5205/reuol.9763-85423-1-SM.1104201731

12. Almeida OA, Santos WS, Rehem TC, Medeiros M. Envolvimento da pessoa com doença renal crônica em seus cuidados: revisão integrativa. Ciênc Saúde Coletiva. 2019;24(5):1689-98. doi: 10.1590/1413-81232018245.04332019

13. Lotfi M, Zamanzadeh V, Valizadeh L, Khajehgoodari M. Assessment of nurse-patient communication and patient satisfaction from nursing care. Nurs Open. 2019;6(3):1189-96. doi: 10.1002/nop2.316

14. Aiken LH, Sloane DM, Ball J, Bruyneel L, Rafferty AM, Griffiths P. Patient satisfaction with hospital care and nurses in England: an observational study. BMJ Open. 2018;8:e019189. doi: 10.1136/bmjopen-2017-019189

15. Sun H, Liu H, Li J, Wang X. The patterns of graded psychological nursing care for patients after cardiothoracic surgeries. Iran J Public Health[Internet]. 2017 [cited 2020 Jun 22];46(7):899-905. Available from: https://www.ncbi.nlm.nih.gov/pmc/articles/PMC5563871/pdf/ IJPH-46-899.pdf

16. Vinuto J. A amostragem em bola de neve na pesquisa qualitativa: um debate em aberto. Temáticas. 2014;22(44):203-20. doi: 10.20396/ temáticas.v22i44.10977

17. Bardin L. Análise de conteúdo. São Paulo: Edições 70; 2016.

18. Guzzo F, Boing E, Nardi AL. Da paralisação dos rins ao movimento da vida: percepções de pessoas em tratamento de hemodiálise. Rev Abordagem Gestalt [Internet]. 2017 [cited 2020 Jun 22];23(1):22-31. Available from: http://pepsic.bvsalud.org/pdf/rag/v23n1/v23n1a04.pdf

19. Santos BP, Lise F, Paula EA, Rodrigues LP, Castelblancos DC, Schwartz E. Chronic renal insufficiency: an integrative review on studies with a qualitative approach. Rev Enferm UFPE. 2017;11(12):5009-19. doi: 10.5205/1981-8963-v11i12a15211p5009-5019-2017

20. Andrade CG, Costa SF, Lopes ME, Oliveira RC, Nóbrega MM, Abrão FM. Communication of difficult news to patients without possibilities of healing and family members: the role of the nurse. Rev Enferm UERJ. 2014;22(5):674-9. doi: 10.12957/reuerj.2014.5748

21. Silva AS, Silveira RS, Fernandes GF, Lunardi VL, Backes VM. Percepções e mudanças na qualidade de vida de pacientes submetidos à hemodiálise. Rev Bras Enferm. 2011;64(5):839-44. doi: 10.1590/S0034-71672011000500006

22. Silva AC, Souza AT, Arenas VG, Barros LF. Ação do enfermeiro na prevenção da doença renal crônica: uma revisão integrativa. SANARE [Internet]. 2015 [cited 2020 Jun 23];14(2):148-55. Available from: https://sanare.emnuvens.com.br/sanare/article/view/840/511

23. Santos BP, Oliveira VA, Soares MC, Schwartz E. Chronic kidney disease: relation of patients with hemodialysis. ABCS Health Sci. 2017;42(1):814. doi: 10.7322/abcshs.v42i1.943

24. Coitinho D, Benetti ER, Ubessi LD, Barbosa DA, Kirchner RM, Guido LA, et al. Intercorrências em hemodiálise e avaliação da saúde de pacientes renais crônicos. Av Enferm. 2015;33(3):362-71. doi: 10.15446/av.enferm.v33n3.38016

25. Santos BP, Viegas AC, Feijó AM, Lise F, Schwartz E. It was/wasn't everything I had imagined: advantages and disadvantages after kidney transplantation. Rev Gaúcha Enferm. 2016;37(3):e60135. doi: 10.1590/1983-1447.2016.03.60135

26. Beber GC, Fontela PC, Herr GE, Winkelmann ER. Qualidade de vida de pacientes transplantados renais após longo período do transplante. Saúde Pesqui. 2017;10(1):163-70. doi: 10.177651/1983-1870.2017v10n1p163-170

27. Pereira N, Cardoso J. O retorno do paciente renal crônico às atividades produtivas após o transplante renal. Rev Ter Ocup Univ São Paulo. 2017;28(2):221-9. doi: 10.11606/issn.2238-6149.v28i2p221-229 
28. Brito DC, Paula AM, Grincenkov FR, Lucchetti G, Sanders-Pinheiro H. Analysis of the changes and difficulties arising from kidney transplantation: a qualitative study. Rev Latino-Am Enfermagem. 2015;23(3):419-26. doi: 10.1590/0104-1169.0106.2571

29. Santos BP, Lise F, Feijó AM, Garcia RP, Schwartz E. Care carried out by people with renal transplants for organ maintenance. Rev Enferm UFPE. 2017;11(8):3108-21. doi:10.5205/reuol.11064-98681-4-ED.1108201716

30. Prates DS, Camponogara S, Arboit EL, Tolfo F, Beuter M. Kidney transplant: perceptions from patients and healthcare professionals about kidney transplants. Rev Enferm UFPE. 2016;10(4):1264-72. doi: 10.5205/reuol.8464-74011-1-SM.1004201613

31. Conceição AICC, Marinho CLA, Costa JR, Santana JR, Silva RS, Lira GG. Perceptions of chronic kidney patients in the refusal of the kidney transplantation. Rev Enferm UFPE. 2019;13(3):664-73. doi: 10.5205/1981-8963-v13i03a237487p664-673-2019

32. Brito EV, Daurta MC, Rocha FC, Cruz IB, Andrade Neto GR, Barbosa GP, et al. O significado, as vivências e perspectivas de pacientes submetidos ao transplante renal. REAS. 2018;17(e223):1-8. doi: 10.25248/reas.e223.2019

33. Pedroso VS, Siqueira HC, Andrade GB, Medeiros AC, Tolfo F, Moura B. The nurse and the model of living of the renal transplanted user: seeking the quality of life. Rev Pesqui: Cuid Fundam. 2019;11(1):241-7. doi: 10.9789/2175-5361.2019.v11i1.241-247

34. Abreu IS, Nascimento LC, Lima RA, Santos CB. Children and adolescents with chronic kidney disease in haemodialysis: perception of professionals. Rev Bras Enferm. 2015;68(6):1020-6. doi: 10.1590/0034-7167.2015680604i 